\title{
The Modern Corporation and Private Property Revisited: Gardiner Means and the Administered Price
}

\author{
William W. Bratton*
}

\section{INTRODUCTION}

The Modern Corporation and Private Property ${ }^{1}$ famously sets out two, apparently contradictory, lines of thought. ${ }^{2}$ One line, set out in Books II and III, resonates comfortably with today's shareholder-centered corporate legal theory. Here, the book teaches that management duties should be intensified in the wake of separated ownership and control: managers should be viewed as trustees for the shareholders and should exercise their wide-ranging powers for the shareholders' benefit. ${ }^{3}$ The other line of thought emerges in Books I and IV, where The Modern Corporation encases this shareholder trust model in discussions of corporate power and social welfare, discussions that resonate today with those who advocate stepped-up government regulation of corporate conduct and corporate social responsibility. Here, the separation of ownership and control implies public responsibilities. The rhetoric flies high: "[I]t is entirely possible ... that the corporate profit stream in reality no longer is private property, and that claims on it must be adjusted by some test, other than that of property right.". The "rigid enforcement of property rights" of passive shareholders would have to give way to a "convincing system of community obligations." Management, moreover, must develop into a "purely neutral technocracy." In order to meet these

\footnotetext{
* Nicholas F. Gallicchio Professor of Law, and Co-Director, Institute for Law \& Economics, University of Pennsylvania Law School; Research Associate, European Corporate Governance Institute. My thanks to Chuck O'Kelley and the participants at Berle X for many helpful comments.

1. Adolf A. Berle, JR. \& Gardiner C. Means, The Modern Corporation and Private PROPERTY (Macmillan 1933) (1932) [hereinafter BERLE \& MEANS].

2. See William W. Bratton, Berle and Means Reconsidered at the Century's Turn, 26 J. CoRP. L. 737 (2001)

3. Id. at 247-76.

4. Id. at 247.

5. BERLE \& MEANS, supra note 1 , at 356.

6. Id. at 353-56.
} 
technocratic obligations, corporate leaders should "set forth a program comprising fair wages, security to employees, reasonable service to their public, and stabilization of business."

In previous work, Michael Wachter and I have shown that The Modern Corporation's contradictions can be explained by reference to the context in which it was written. ${ }^{8}$ The book had a long gestation, spanning the late 1920s, the Crash, and the early years of the Great Depression. Many, including Berle, reordered their political economic views during those years. The Modern Corporation's various parts capture Berle at different points in the timeline, beginning in the boom years as a friend of the shareholders, and ending in the depths of the Depression as an advocate of corporate advancement of national social welfare policies. Indeed, Berle emerged as a leading figure in the national debate over the appropriate policy response to the economic crisis, a debate just getting started upon the book's publication in the spring of 1932. Many looked to Franklin Delano Roosevelt not only to win that year's election but also to follow the lead of many European leaders of the time and adopt corporatism as the political economy of the United States. Berle, who joined FDR's inner circle during the 1932 campaign, was a leading advocate of a corporatist approach. ${ }^{9}$ Wachter and I show that The Modern Corporation's most famous sequence, a final chapter (Book IV, Chapter IV), entitled "The New Concept of the Corporation," 10 extensively overlaps the "New Individualism" speech that Berle (and his wife Beatrice) wrote for FDR. ${ }^{11}$ The speech, the most radical of the 1932 campaign, ${ }^{12}$ presaged the economic program of the New Deal, in particular the corporatist National Industrial Recovery Act (NIRA) enacted in June 1933. ${ }^{13}$

This essay casts additional light on The Modern Corporation's corporatist precincts, shifting attention to the book's junior coauthor, Gardiner C. Means. Means is accurately remembered as the generator of Book I's statistical showings - the description of deepening corporate concentration and widening separation of ownership and control. He is

7. Id.

8. See William W. Bratton \& Michael L. Wachter, Shareholder Primacy's Corporatist Origins: Adolf Berle and the Modern Corporation, 34 J. CORP. L. 99 (2008).

9. Id. at 109-12.

10. See BERLE \& MEANS, supra note 1, at 352-57. For a textual explication of the chapter, see William W. Bratton \& Michael L. Wachter, Tracking Berle's Footsteps: The Trail of The Modern Corporation's Last Chapter, 33 SEATTLE U. L. ReV. 849 (2010).

11. Davis W. Houck, FDR's Commonwealth Club Address: Redefining Individualism, Adjudicating Greatness, 7 RHETORIC \& PUB. AFF. 259, 259-60 (2004).

12. Jordan A. Schwarz, Liberal: Adolf A. BERLE AND the Vision of AN AMERICAN ERA 79 (1987); Franklin D. Roosevelt, Governor of N.Y., Address at the Commonwealth Club in San Francisco, California (Sept. 23, 1932).

13. Bratton \& Wachter, supra note 8 , at 109-18. 
otherwise more notable for his absence than his presence in today's discussions of The Modern Corporation. This essay fills this gap, describing the junior coauthor's central concern-a theory of administered prices set out in a Ph.D. dissertation Means submitted to the Harvard economics department after the book's publication.

The pricing theory articulated in the dissertation is barely alluded to in The Modern Corporation, amounting to a sort of missing chapter. This essay is on very good authority in so characterizing the material, for it takes its cue from Means himself. In 1982, Means recorded his own reflections on the book's meaning, both as of the time of publication and in retrospect. The occasion was a conference marking the book's fiftieth anniversary held at the Hoover Institution of Stanford University on November 19 and 20. ${ }^{14}$ There, Means explained that corporate concentration presented a problem of vastly greater magnitude than did separated ownership and control and that the book's central points could be found not in the trust model or the descriptions of management defalcation, but in an opaque passage at the end of Book I, Chapter III, ${ }^{15} \mathrm{a}$ passage that becomes intelligible only by reference to Means's dissertation.

For Means, the book and the dissertation were a single project. The book's statistical chapters went on to make up the lion's share of the dissertation. The theory of administered prices, omitted from the book but included as the final part of the dissertation, lays out the statistical results' implications for public policy. It amounted to a new description of the economy's pricing mechanism, a description built on a skeptical evaluation of the economy's self-corrective capability. Means believed Adam Smith's picture of supply, demand, and automatic market correction had been partially eclipsed by inflexible pricing administered by corporate managers. Growing corporate concentration exacerbated these "administrated" prices' distortionary effects. ${ }^{16}$ Means's theory explained the Great Depression's persistence and yielded a detailed list of problems to be addressed by a new regulatory state. ${ }^{17}$ Reference to the dissertation explains in hard economic terms why the authors thought private property needed to be pushed aside and just what they thought that "neutral technocrats" could do to enhance social welfare.

Means would continue to refine his theory of administered prices for the rest his career in the teeth of objections raised by more conventional economists, both neoclassical and neo-Keynesian. The book project set the

14. Thomas Gale Moore, Introduction, 26 J. L. \& ECON. 235 (1983).

15. BERLE \& MEANS, supra note 1 , at $45-46$.

16. See infra text accompanying notes $78-90$.

17. See infra text accompanying notes 94-99, 118. 
pattern of mainstream rejection: even as Means did receive a Ph.D. from Harvard in 1933, his committee rejected the dissertation's theoretical part. ${ }^{18}$

Part I reconstructs the scene at the Hoover conference based on the papers and comments later published in the Journal of Law and Economics. It was a hothouse occasion, with the Chicago tribe gathered to present work that took the occasion of the fiftieth anniversary to bury The Modern Corporation then and forever. They did not succeed, even as some of what they said resonates more loudly today than it did at the time the papers were given. Means, a non-Chicago minority of one on the publication list, stalwartly defended both the book and his later contributions in a paper that amounts to an eleven o'clock reprise of a life's work.

Part II turns the clock farther back to the time of The Modern Corporation's composition and publication, describing the Berle-Means collaboration and taking a closer look at what Means brought to the table in the book's Part I. The missing chapter is then sketched in by reference to the unpublished dissertation and its early-stage articulation of a theory of administered prices. The dissertation's exposition delivers the reader to the same points made in Book IV, Chapter IV, providing an essential explication.

Part III describes Means's later career, comparing it to that of his erstwhile coauthor. Means was a civil servant, a practicing economist, an entrepreneur, and a consultant, but never an academic. His fortunes as an economist waned badly as the 1930 s came to a close. ${ }^{19}$ Means was a planner, and the planners' influence declined in the wake of the failure of the NIRA. ${ }^{20}$ They lost their place at the policy table at the end of the decade, eclipsed by neo-Keynesians advocating fiscal stimulus. Economic expansion after World War II meant further marginalization for Means, even as Berle made adjustments that kept him on the national political economic stage.

Part IV takes up the last years of Means's career, when he enjoyed a comeback due to an economy that stagnated even as inflation continued. The mainstream macroeconomists whose ministrations had consigned Means to the policy wilderness had no explanation for this "stagflation" and, as a result, fell into disrepute. Means, however, did have a theory. $\mathrm{He}$ had, back in the 1960s, reformulated his theory of administered prices to explain the stagflation phenomenon. ${ }^{21}$ This returns us to Stanford in 1982,

18. See infra text accompanying note 71 .

19. See infra text accompanying note 129 .

20. Id.

21. See infra text accompanying note 147. 
where Means gave a paper that described his diagnosis of and solution for stagflation. ${ }^{22}$ Ironically, inflation was fading and the stock market was signaling economic expansion even as Means spoke. These developments would in turn usher orthodox free market economics back to the forefront, a return from the policy wilderness to which the market had been consigned by The Modern Corporation a half century earlier.

\section{PALO Alto, 1982}

The Hoover Institution conference featured such luminaries as George Stigler, ${ }^{23}$ Harold Demsetz, ${ }^{24}$ Eugene Fama, Michael Jensen, ${ }^{25}$ and Oliver Williamson, ${ }^{26}$ each in different ways pronouncing that the separation of ownership and control no longer presented a problem, if indeed it ever had. The thrust of the papers is that, contrary to Berle and Means's thesis, free markets and corporate contracting work together to constrain management moral hazard. And, while ownership and control had indeed separated, no structural infirmity should be diagnosed as a result. Corporate control arrangements instead should be seen as rational solutions to problems arising in the course of complex production.

Two conference papers launch direct attacks on The Modern Corporation, going back to the status quo at the time it was published and challenging its accuracy. One of these, from George Stigler and Claire Friedland, ${ }^{27}$ interposes a headlong empirical challenge to the proposition that self-perpetuating managers were in control and running their companies in a self-serving way. ${ }^{28}$ The paper draws on Means's statistical arrangement of the country's 200 largest companies into control categories based on stock ownership. ${ }^{29}$ Means cordoned off private ownership, majority shareholder control, and pyramiding into separate categories. He added a fourth "minority control" category, in which a stockholder held between $20 \%$ and $50 \%$ of the shares, and then put corporations that did

22. See infra text accompanying note 149.

23. See George J. Stigler \& Claire Friedland, The Literature of Economics: The Case of Berle and Means, 26 J. L. \& ECON. 237 (1983).

24. See Harold Demsetz, The Structure of Ownership and the Theory of the Firm, 26 J. L. \& ECON. 375 (1983).

25. See Eugene F. Fama \& Michael C. Jensen, Agency Problems and Residual Claims, 26 J. L. \& ECON. 327 (1983); Eugene F. Fama \& Michael C. Jensen, Separation of Ownership and Control, 26 J. L. \& ECON. 301 (1983).

26. See Oliver E. Williamson, Organization Form, Residual Claimants, and Corporate Control, 26 J. L. \& ECON. 351 (1983). Frank Easterbrook, Daniel Fischel, and Henry Manne also were in attendance but do not seem to have presented. Id. The conference had been suggested by Stanford Law's Ken Scott. Moore, supra note 14.

27. Stigler \& Friedland, supra note 23.

28. Id. at 247.

29. Not without complaint. See id. at 248 (noting that control contestability was not accounted for). 
not fall into any of the categories into a fifth category called "management control." ${ }^{30}$ In his final tally, Means showed that 44\% of American corporations by number and $58 \%$ by value were under management control. ${ }^{31}$

Stigler and Friedland tested the policy implications of Means's numbers, taking executive salary data from three separate studies undertaken in the late 1920s and 1930s. Stigler and Friedland regressed the salaries on the logarithm of the corporations' assets and a dummy variable for control type. ${ }^{32}$ Nothing that related the compensation arrangements to the control types emerged from any of the three data sets. ${ }^{33}$ The implication, said Stigler and Friedland, was that managers in control did not set their own salaries, as Berle and Means had implied. ${ }^{34}$ Stigler and Friedland also gathered up statistics on corporate profitability from the same periods. They hypothesized that, under the Berle and Means analysis, the blockholder-controlled corporations should do better. ${ }^{35}$ Regression of the profitability numbers on corporate assets and control types showed that control had a significant effect on performance in only one of five regressions, once again purportedly falsifying Berle and Means. ${ }^{36}$

The second direct attack came from Robert Hessen, a Hoover Institution fellow. ${ }^{37}$ Hessen took Berle and Means to task for failing to discuss other forms of business organization. With large partnerships run by delegated managers, for example, there also was separation of management and investment. ${ }^{38}$ Berle and Means similarly ignored the property law doctrine applicable to noncorporate enterprise-joint ownership. Reference to the law of joint ownership showed that comingled property rights had been intrinsic to group enterprise long before the twentieth century. It followed that the developments highlighted by Berle and Means were matters of degree rather than changes in kind. ${ }^{39}$ The conclusion was that separation of ownership and control was an ordinary phenomenon in business enterprise; a phenomenon that, by itself, provided no justification for government regulation. ${ }^{40}$

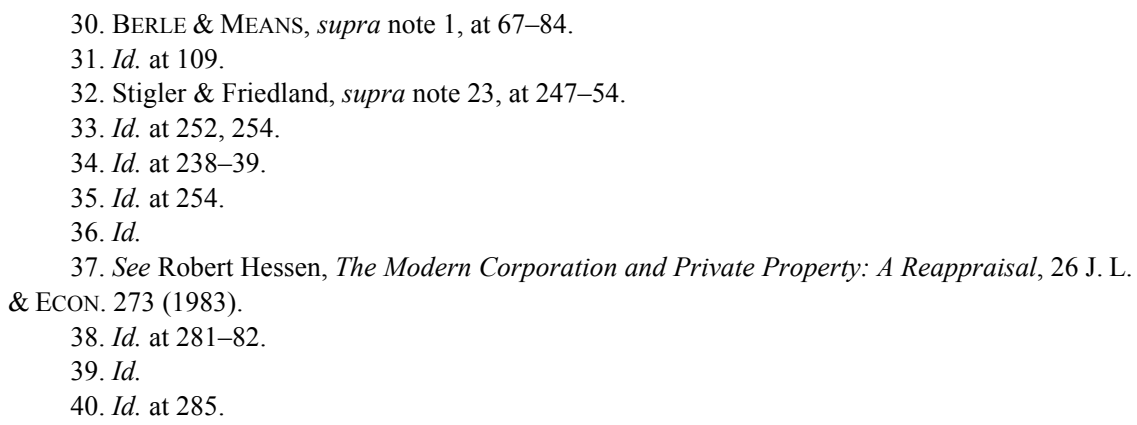


Means made the comment on Hessen, shrugging off the paper with comments that applied equally to the attack by Stigler and Friedland. Said Means, by focusing only on the separation of ownership and control ${ }^{41}$ Hessen was distorting the book's message. ${ }^{42}$ The Modern Corporation, Means said, had never concluded that big, management-controlled corporations cannot be engines of efficiency. Neither did the book say that directors had no right to control corporate property they do not own, nor that the ownership of shares somehow falls outside of the private property system. ${ }^{43}$ Nor did the book purport to describe fundamental changes in the basic characteristics of business organizations, making Hessen's attack irrelevant. $^{44}$

The question assayed in the book, according to Means, was instead whether public policies formulated in an era when enterprises had been small could be expected to continue to work well when a significant part of production was conducted by giant firms with dispersed owners. ${ }^{45}$ What mattered in the book, accordingly, was less the discussion of separated ownership and control than the discussion of increasing concentrationMeans's showing that one-third of the national wealth lay in the hands of 200 large corporations and projection that, given continuation of the present rate of growth of that relative share, seventy percent of economic activity would be carried on by 200 corporations by $1950 .{ }^{46}$ From this showing, said Means, the book concluded that the modern corporate economy had superseded the classical, Smithian picture of a successfully self-correcting market economy. New concepts of economic relations were needed. ${ }^{47}$

Means suggested that an observer really interested in understanding The Modern Corporation should consult pages 45 to 46 thereof, which set forth a series of five points as a conclusion to the description of concentrating economic power in Book I, Chapter III. ${ }^{48}$ The points merit a close look. First came a recommendation about matters for future inquiry: we now needed to study the behavior of large producing units rather than the behavior of the economy's small competitors. ${ }^{49}$ Second came an observation about competition - the nature of competition had

41. Gardiner C. Means, Hessen's “Reappraisal,” 26 J. L. \& ECON. 297, 298 (1983) [hereinafter Means, Hessen's Reappraisal].

42. Id. at 297.

43. Id. at 299.

44. Id.

45. Id. at 300 .

46. BERLE \& MEANS, supra note 1, at 9, 37, 47.

47. Means, Hessen's Reappraisal, supra note 41, at 297.

48. BERLE \& MEANS, supra note 1, at 18-46.

49. Id. at 45 . 
[Vol. 42:591

changed and duopoly now mattered more than classical free markets. ${ }^{50}$ Third, the book noted that an increasing proportion of production was for "use" rather than for "sale," implying that the profit motive was no longer driving decision making within producing companies. ${ }^{51}$ Fourth, the nature of capital had changed so as to be comprised more of going concern value than tangible asset value. ${ }^{52}$ Fifth, blind market forces no longer governed the economy and economic power was instead concentrated in a small number of hands, making corporations social institutions. ${ }^{53}$

Cross-referencing Means's comment at Hoover to pages 45 and 46 leaves one in a typical Modern Corporation state of confusion; a condition akin to that experienced by a first-time reader of the vague sentences in Book IV, Chapter IV. The longer one looks at this fivefold assertion, the more questions one has. How exactly had the nature of competition changed? The reference to a "duopoly" that mattered more than the classical free market provided no explication because the "duopoly" was not otherwise defined in Book I, Chapter III. Why was it so important that big, vertically integrated companies now produced goods that they consumed themselves rather than producing everything for an exterior market? How did this somehow eliminate the constraints of product market competition? Since when did rising going concern values relative to asset values denude the profit motive of motivational force, making for a policy problem? And wasn't that final reference to power in the hands of a few just the standard invocation against corporate bigness typical of mid-twentieth century antitrust? The book offers no answers to these questions.

But Means did answer the questions elsewhere. The five-point list at the end of Book I, Chapter III was a gesture in the direction of the theoretical part of Means's dissertation, the content of which is described in this essay's next Part.

II. NEW YORK, 1927-1933

Adolf Berle first took up residence at Columbia Law School, where he would spend the rest of his career, in $1927 .{ }^{54} \mathrm{He}$ started on a soft money basis, occupying an office and doing adjunct teaching at the business school while he waited for a permanent law school faculty line to become available. ${ }^{55}$ Interim support came from a Rockefeller Foundation grant for

50. Id.

51. Id.

52. Id. at $45-46$

53. Id. at 46.

54. William W. Bratton, Berle and Means Reconsidered at the New Century's Turn, 26 J. CoRP. L. 737,750 (2001).

55. Id. 
a research project that eventually became The Modern Corporation. ${ }^{56}$ The grant stipulated an "interdisciplinary" study of corporations to be conducted with an economist. ${ }^{57}$ Berle chose Means, then a graduate student, later describing him as a "statistical and economic research assistant," 58 who contributed the book's empirical studies of corporate concentration and dispersed share ownership. Berle eventually conceded co-authorship and one-third of the royalties. ${ }^{59}$

Means, although a student, was only one year younger than Berle ${ }^{60}$ and a family friend. Berle and Means were "old bunkmates" from their training at the army's officer candidate school at Plattsburg, New York during World War I. ${ }^{61}$ Their respective spouses, Beatrice Bishop and Caroline Ware, had been undergraduate friends at Vassar. Bishop and Ware had remained close and jointly intervened to get Means onto the Rockefeller project. ${ }^{62}$

Means's interest in the workings of the economy is said to date from his experience as a relief organizer in post-war Turkey. He supervised a village of 1,000 orphans and there observed a market-dominated production process that perfectly manifested Adam Smith's description of supply, demand, and price discovery. ${ }^{63}$ The interesting thing, for Means, was a marked contrast with what he understood of production and pricing in the United States. ${ }^{64}$

Upon his return, Means studied at the Lowell Textile Institute ${ }^{65}$ and then went into business, starting up a factory that manufactured fine blankets, a business he ran from 1922 to $1929 .{ }^{66}$ Means found himself able to set product prices at will, deepening the sense of divergence between

56. The book project, the grant, and the Columbia appointment were tightly bound together. The grant came first, awarded by a new not-for-profit, the Social Science Research Council, which in turn was funded by Rockefeller. William Z. Ripley, much admired by both Berle and Means, was on the Council's board. The grant was conditioned on an academic appointment. Berle, the grant in hand, but not the appointment, shopped himself first to Yale, which had no interest. But Harlan Stone, the dean at Columbia, took the bait. AdOlF A. Berle, JR., NAVIGATING the RAPIDS, 1918-1971, at 20-21 (Beatrice Bishop Berle \& Travis Beal Jacobs eds., 1973) [hereinafter BERLE, NAVIGATING].

57. SCHWARZ, supra note 12, at 51.

58. Id.; BERLE, NAVIGATING, supra note 56, at 21.

59. SCHWARZ, supra note 12 , at 58-59.

60. Berle lived from 1895 to1972; Means lived from 1896 to 1988

61. BERLE, NAVIGATING, supra note 56, at 21; THEODORE ROSENOF, ECONOMICS IN THE LONG Run: NEW DEAL TheORISTS \& THEIR LegaCiES, 1933-1993, at 28 (1997). He later trained as a pilot and had a reputation as a daredevil. Id.

62. ROSENOF, supra note 61 , at 29.

63. Gardiner C. Means, Remarks upon the Receipt of Veblen-Commons Award, 9 J. ECON. Issues 149, 149-50 (1975) [hereinafter Means, Remarks].

64. AnNe Firor Scott, Pauli Murray \& Caroline Ware: Forty Years of LetTers in BLACK \& WHITE 4 (2006).

65. ROSENOF, supra note 61, at 29.

66. Means, Remarks, supra note 63, at 150. 
Smith's description and contemporary real-world operations. ${ }^{67}$ Multitasking as he ran the blanket business, he enrolled in Harvard Business School. He there fell under the influence of W.Z. Ripley and emerged with a master's degree in 1927. ${ }^{68}$ Enrollment in the doctoral program at Harvard followed immediately, even as Means also signed on with Berle at Columbia, ${ }^{69}$ with the work produced for the book substantially overlapping the chapters in the Ph.D. dissertation. Like Berle, Means worked on FDR's 1932 presidential campaign. ${ }^{70}$ As noted above, the Ph.D. was duly granted in 1933 but only at the pain of the rejection of the dissertation's theoretical discussion, ${ }^{71}$ the material obliquely referred to at the end of Part I, Chapter III of The Modern Corporation.

Means titled the dissertation The Corporate Revolution. Its statistical part, like that of The Modern Corporation, demonstrated (1) that an increasing amount of economic activity is conducted by corporations, (2) that super-sized corporations played an increasing role, (3) that share ownership was increasingly dispersed, and (4) that an increasing number of large corporations were manager-managed. ${ }^{72}$

The theoretical part of the dissertation described the implications of these findings for classical economic orthodoxy. In the orthodox picture, supply and demand set the prices of goods traded in free markets. There results a disciplined, self-correcting economic system in which upward swings automatically follow economic downturns caused by falling demand. External shocks occur but do not in the long run distort the system's fundamental soundness; government intervention accordingly should be avoided. ${ }^{73}$ The Great Depression cast doubt on these confident predictions and the resulting noninterventionist prescription.

Means posed an alternative approach. He had reached the conclusion that the orthodox picture, which worked well for the simple trading

67. SCOTT, supra note 64 , at 4.

68. WARREN J. SAMUELS \& SteVEn G. MEDEMA, GARDinER C. MEANS: INSTITUTIONALisT AND POST KEYNESIAN 7 (1990).

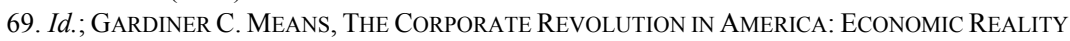
VS. ECONOMIC THEORY 15 (1962) [hereinafter MEANS, REVOLUTION].

70. SCOTT, supra note 64 , at 6.

71. ROSENOF, supra note 61, at 29.

72. Means, Revolution, supra note 69 , at 15 . The reference is to a summary of the thesis that Means published in a 1962 collection of essays. The remaining copy of the thesis, a typescript with handwritten corrections and changes, does not preserve the chapters that found their way into the book. An unpaginated sheet, inserted after page $8 \mathrm{~B}$, states that those chapters are omitted because they appeared elsewhere. Gardiner C. Means, The Corporate Revolution, insertion after 8B (1933) (unpublished manuscript) (on file with the Franklin D. Roosevelt Library, Gardiner C. Means Papers, Series I, Box 2) [hereinafter Means, Corp. Revolution].

73. See ROSENOF, supra note 61 , at 5. 
situations he observed in Turkey, no longer accurately described the working of a complex modern economy. ${ }^{74}$

His dissertation offered four broad points to this end. First, markets for many products no longer set prices, which were instead administered by corporate managers. ${ }^{75}$ Second, the costs of goods sold were no longer determined by the production process but were instead indeterminate. ${ }^{76}$ Third, the process of saving and investment was now dualistic, with a corporate side and an individual side. ${ }^{77}$ And fourth, the profit motive no longer sufficed as an explanation for production activity. ${ }^{78}$

\section{A. The Administered Price and Administrative Competition}

The first point, the rise of the administered price, was primus inter pares. Means distinguished classical market pricing from modern corporate pricing. In the classical market, the price did not precede the trade but was instead determined by the trade as supply met demand. ${ }^{79}$ Large corporations priced differently; managers would fix the price of the good in advance of the sale, and this "administered" (or "engineered") price would stick for a period of time ${ }^{80}$ As the corporate producing sector grew, prices in the overwhelming majority of conventional markets for manufactured goods became fixed over time. The product markets, as a result, ceased to equate supply and demand, except by coincidence. ${ }^{81}$

It followed that pictures of economic activity in standard demand curves no longer were accurate, for they assumed perfect price flexibility where it did not necessarily exist. ${ }^{82}$ Not that supply and demand for a given product remained inflexibly apart forever. There would be a long run tendency for the proportionate discrepancy to decrease, but an absolute discrepancy would persist without decrease. ${ }^{83}$

There was a stark follow-up point: a disequilibrium between supply and demand caused by a drop of demand did not result in a fall in price. Instead of lowering the price in response to a falling demand, a rational corporate manager would make an internal adjustment, cutting back on

74. Means, Remarks, supra note 63, at 150-51.

75. Means, Corp. Revolution, supra note 72, at 124-25.

76. Id. at $146-51$.

77. Id. at $152-59$.

78. Id. at $160-76$.

79. Id. at 125 .

80. Id. at $134-35$.

81. Id. at 135 .

82. Id. at 125 .

83. Id. at 140 . 
levels of production and reducing levels of employment matters as to which flexibility had been retained. ${ }^{84}$

Means's discussion had a remarkable implication. Given the zone of administrative discretion he described, the choice to cut back on production instead of competing on price could even make the firm more valuable. The further implication was that, as Means had noted on page 45 of The Modern Corporation, market competition had changed in character. ${ }^{85}$ It had become less intense as the various producing sectors became more and more concentrated ${ }^{86}$-Means would later call this "administrative competition." 87 The duopoly to which Means cryptically referred on page 45 now comes clearly into view. Means divided the economy into two sectors: one with traditional market-determined prices, the market for agricultural products being the prime example, and the other sector with administered prices. ${ }^{88}$ As the administered sector grew in relation to economy as whole, imbalance and instability resulted ${ }^{89}$

This analysis led directly to an explanation for the Great Depression's depth and persistence. Means articulated it in a famous article published in $1935 .{ }^{90}$ In the classical picture of the economy, if demand fell but the money stock was constant, prices fell. The price drop increased the purchasing power of money, stimulating demand and restoring full employment. In the modern corporate economy, in contrast, inflexible prices prevented automatic correction from occurring in one-

84. Id. ("The flow of goods into any one of these reservoirs may not be closely articulated with the flow of goods out of the reservoir, with the result that at particular times the reservoirs may to a certain extent be filled up or depleted without any effect on price. In such a situation, the effect of fluctuations in demand is to speed up or slow down the flow through these reservoirs, working finally back to the factors of production themselves, where, because the rates of wages and interest are also administratively determined, the immediate effect is to throw out of use the factors of production rather than to reduce their price.").

85. See supra text accompanying note 50.

86. Gardiner C. Means, Corporate Power in the Marketplace, 26 J. L. \& ECON. 467, 469, 470 (1983) [hereinafter Means, Corporate Power]. Although corporate size and concentration were at the descriptive center of Means's theory, he differed sharply with the economic description that motivates antitrust analysis, which starts with the classical free market picture and then identifies, and in some cases prohibits, exceptions thereto. ROSENOF, supra note 61, at 36-37. For Means, administered prices were a natural outgrowth of complex production. Once placed under regulatory control, the concentration would be rendered benign.

87. Means, Corporate Power, supra note 86, at 470.

88. Id. at 467,470 .

89. Means, Corp. Revolution, supra note 72, at 143 (describing unemployment and the consequent falloff of demand).

90. Gardiner C. Means, Price Inflexibility and the Requirements of a Stabilizing Monetary Policy, 30 J. AM. STAT. Ass'N 401, 405 (1935) [hereinafter Means, Price Inflexibility]. 
half of the economy, retarding a return to stability. ${ }^{91}$ Means would call for monetary expansion as a corrective. ${ }^{92}$

\section{B. The Indeterminacy of Cost}

Let us now return to the thesis and its second point-the indeterminacy of product cost. This amounted to a more particular observation about the pricing process; an observation that underscored the picture of an administered price and its destabilization of classical economic assumptions. In the classical picture, price minus cost equals profit and the profit motive is the engine driving the economic train. Product cost and market price together determine production and employment decisions. To say that cost is indeterminate inserts managerial discretion into this basic equation, undercutting the motivational story and making the manager an independent decisionmaker.

Means's more particular case devolved on overhead charges. He characterized them as "joint costs," meaning that the firm experienced them on an aggregate basis and not as attached to any particular product. ${ }^{93}$ As he saw it, in a large operation, readily attributable product costs were at a minimum with a lot of the cost arbitrarily lumped into overhead (and depreciation), with these items representing a steadily rising proportion of overall costs. ${ }^{94}$ A producer would accordingly view the profit implications of a fall in demand on a firm-wide basis rather than tying its profit calculations to each unit of output produced. This insulated the producer's economic behavior from determination by the price point in the market.

\section{Saving and Investment}

The third point - the duality of saving - divides the world into corporate savers and individual savers. The corporate savers invest in capital goods while the individual savers invest in interests in capital goods, also known as corporate stocks and bonds. ${ }^{95}$ The capital goods and the securities are priced in different markets. Distortionary effects follow: even though the value in both markets comes from the same capital goods, prices in the two markets could move in opposite directions - once again negating the standard account, in this case the one from macroeconomics.

Means described a number of distorted scenarios. For example, he posited a negative shock that triggers a fall in demand and in prices.

91. Means, Corporate Power, supra note 86, at 404.

92. Means, Price Inflexibility, supra note 90, at 409-13.

93. Means, Corp. Revolution, supra note 72, at 147-49 (setting out examples of cost accounting).

94. Id. at 146, 149-50. Numerous examples are offered: the cost of goods sold in a shoe store, $i d$. at 147; a woolen mill, id. at 148-49; meatpacking, id. at 150.

95. Id. at $152-53$. 
Corporations, as a result, stop investing and issuing new securities. Meanwhile, individuals are still saving, bidding up the prices of a static supply of investment securities. Securities prices thus rise even as the economy stalls, until such time as savings decrease or corporations once again issue new securities. ${ }^{96}$

Alternatively, Means posed that the shock and the cessation of corporate investment could cause savings to fall and force many individuals to consume out of their accumulated stocks of savings. ${ }^{97}$ Downward pressure on stock prices would result. The value of the savings stock would fall with them, so that the savings retrenchment would not lead to an increase in the amount of goods actually consumed by individuals (and, by hypothesis, an economic recovery). Although the individuals had in substance invested their savings in corporate capital goods, the individuals had no way to access these investments directly for retrenchment purposes - their access was limited to firm-issued securities, the prices of which were falling below intrinsic value in a separate, disconnected market. Access to the real value of individual savings was being blocked by the separation of ownership and control:

Only by the intermediary action of corporate control, would this be possible. If no such action by control occurs, the value of securities will melt away while the goods in which the securities represent an interest, though badly wanted by the community, will remain on the shelves of the corporation. ${ }^{98}$

It seemed, then, that most important saving decisions being made in the economy were in the hands of corporate managers rather than saving individuals. The managers controlled not only the capital goods themselves but the decision as to the issuance of new securities for purchase by individual savers. ${ }^{99}$ Serious disequilibrium followed for the economy when the two markets failed to move in consonance. ${ }^{100}$ Indeed, Means's scenario suggests an explanation for an apparently endless Great Depression following on the heels of a stock market crash.

\section{The Profit Motive}

Administered pricing and the separation of ownership and control, taken in conjunction, yield the fourth point, which concerns the profit motive. In the classical picture, the desire for profits motivates the entrepreneurs who produce the goods. Things work differently in the

96. Id. at 154 .

97. Id. at $156-57$.

98. Id. at 159 .

99. Id. at 149 .

100. Id. 
modern corporation under separated ownership and control: the shareholder-owners take the profits even as they are unable to perform the function of monitoring to assure efficient operations. This breaks the logic of the classical picture, in which the firm and its profits "belong" to the shareholders. ${ }^{101}$

Means surveyed the day's cutting-edge theory of the firm, describing two opposing points of view. Profits were thought to have three components: return on invested capital, the wages of management, and a third residual category of "pure" profits. ${ }^{102}$ Some thought of pure profits as reward for risk taking and thus properly directed to the shareholders, while others saw pure profits as a reward for the "integrating force" of corporate leadership and thus properly directed to the managers. ${ }^{103} \mathrm{It}$ followed that the profit motive that drove the classical entrepreneurial business had been separated. ${ }^{104}$

Meanwhile, the law did not provide clear instructions as to an appropriate allocation of the profits. Corporate plundering had entered the fact pattern, as stressed in The Modern Corporation. ${ }^{105}$ Even so, Means downplayed the importance of management's fiduciary defalcations. He instead stressed market and institutional limits on management discretion. Sufficient returns had to be directed to risk-bearing shareholders to keep the market receptive to new issues of shares. At the same time, because proxy fights made management power contestable, managers had to keep their "phlegmatic" shareholders reasonably contented. ${ }^{106}$ Accordingly, risk bearing capital did get a cognizable cut of pure profits.

But who should receive the residual of the residual (termed "ex risk profit" by Means)? "The answer," said Means, "must be sought in economic and social considerations." $107 \mathrm{He}$ saw no reason to direct this wealth to the shareholders, who performed no further economic function after having been compensated for bearing risk. Applying economic logic, the scales thus apparently tipped in the managers' direction. Since they were performing an economic function as they operated the firms, compensation with "ex risk profit" had an apparent incentive-based justification. ${ }^{108}$

101. Id. at 165 .

102. Id. at 161 .

103. Id. at $162-64$.

104. Id. at 165 .

105. See BERLE \& MEANS, supra note 1, at 311-12.

106. Id. at $166-68$.

107. Id. at 171.

108. Id. at $172-73$. 
Means rejected this economic logic, ${ }^{109}$ however, and redirected the discussion to the speculative territory on which he and Berle closed The Modern Corporation. The rejected logic only made sense on the classical assumptions that the profit motive would spur efficient production and that a competitive economy would effectively regulate the producers. Concentration of economic power negated both assumptions. In addition, there were diminishing returns on the management incentive side as everlarger profit sums would go into a smaller number of pockets. Meanwhile, concentration enhanced barriers to entry and diminished competitive control. $^{110}$

Means held open the ultimate question regarding the allocation of profits, closing with a question and a suggestion. The question was whether it was still plausible that the profit motive held out a socially effective method of inducing entrepreneurship. ${ }^{111}$ The implicit answer was no. As to what to do with ex-risk profits, maybe the question was whether such profits should be made at all, with managers being modeled not as entrepreneurs but as professionals with public duties. ${ }^{112}$ Whatever the answers to the many open questions, Means was certain of one thing - that his depiction of administered pricing and competition would provide essential assistance in the answers' eventual derivation. ${ }^{113}$

\section{E. Comments}

Add all this up and one returns to The Modern Corporation with answers to many of its open questions. We now have a microeconomic basis for understanding the fifth assertion made in Book I, Chapter III: Adam Smith's invisible hand no longer governed the economy because the power to price goods-indeed, the decision whether to produce the goods in the first place - now was vested in a small number of visible hands. The shift denuded price competition of its disciplinary effect, diluted the incentive effect of the profit motive, and perhaps most importantly, prevented the economy from self-correcting in the wake of a negative shock.

Corporations, viewed against this dysfunctional microeconomic background, fairly could be characterized as social institutionsinstitutions in obvious need of regulation. Furthermore, Means's analysis handed a very specific directive to the regulator-to-be: figure out how to

109. Id. at 171

110. Id. at $175-76$.

111. Id. at $173-74$.

112. Id. at 174 .

113. Id. at 176 . 
manage the price in the interest of the economy as a whole rather than in the exclusive interest of the producing entity.

The Modern Corporation would have made a lot more sense had the theoretical points in the thesis been included as the final chapter of Part I. Why were the points not included? Michael Wachter and I speculated that Berle, as an aspiring FDR Brains Truster vying against others to influence the policies to be articulated by a still-undecided future boss, would have been cautious about laying out a detailed policy program in public. ${ }^{114} \mathrm{~A}$ similar motivation could have been in play in regards to the discussion of administered pricing. ${ }^{115} \mathrm{Or}$, in view of the tentative nature of the policy assertions made in the much better articulated economics of the dissertation, perhaps Berle and Means were astute enough to know that they did not know the answers, just the direction of future inquiry. There also could have been ordinary editorial and authorial concerns. Means's theory would have added to the book's complexity while simultaneously attracting criticism and prompting skepticism.

There may also have been a timing problem. The book was in press, with the final galleys submitted by the authors, by April $1932 .{ }^{116}$ The dissertation was submitted in the following year. ${ }^{117}$ Perhaps the traces of the dissertation that we see on pages 45 and 46 of the book reflect an earlier stage of the project, while the surviving dissertation draft displays the same ideas at a more mature stage of development.

A comparison of the five points on pages 45 and 46 with the exposition in the dissertation supports this inference. Book I, Chapter III, point three - the increase in production for use rather than sale-does not reappear in the thesis, apparently having been replaced by the discussion of cost accounting and overhead. Interestingly, both points-production for use and cost accounting - are probative of a trend toward internal price administration and away from external market control. It seems that Means at some point decided that reference to accounting did the job better than reference to vertical integration. A similar association can be suggested between Book I, Chapter III, point four-the trend toward going concern over asset value - and the dissertation's discussion of saving and investment. In this case, the comparison suggests considerable analytical

114. Bratton \& Wachter, supra note 8 , at 120-22.

115. Means would later note that The Modern Corporation made no attempt to address the basic question as to how to restore the economy. See Means, Corporate Power, supra note 86, at 469.

116. Letter from Adolf Berle to Gilbert Montague (Apr. 20, 1932) (on file with the Franklin D. Roosevelt Library, Adolph Berle Papers, General Correspondence 1928-1940, Box 9) (noting that the galleys were in and that publication was imminent).

117. This is speculation based on the fact that the degree was granted, and the theoretical chapter rejected, in 1933. The dissertation draft amongst the Gardiner Means Papers at the Franklin D. Roosevelt Library is undated. See Means, Corp. Revolution, supra note 72. 
advancement over time. The book's emphasis on the primacy of going concern over asset value does suggest that large corporate producers have special characteristics. But one can think of qualifications: going concern value also exceeds asset value at a mom and pop store. Nor does the value point by itself show us that the classical picture no longer describes either pricing or incentives in a large corporation. The discussion in the dissertation accomplishes much, much more, identifying different markets for the same value source (one for assets and the other for going concern value), bringing in the separation of ownership and control to bear on Means's pricing theory and pointing to concrete distortionary possibilities.

One suspects, then, that the theory of the administered price remained at such an early stage of articulation as to preclude its inclusion in a book published in early 1932. In this scenario, Means's chapter is missing because it was a rough work in process, or perhaps had not yet been written. But the omission might have occurred even if the dissertation draft had been on the table in early 1932. The presentation in the dissertation amounted only to a first crack at what would become for Means a monumental, career-long theoretical enterprise. There is no basis on which to infer that Means deemed the version in the dissertation ready for publication.

\section{WASHINGTON, 1933-1988}

Berle stayed in New York after Roosevelt's inauguration in 1933, not having received an offer of a sufficiently important job in the new administration. ${ }^{118}$ Means, in contrast, went to Washington, where he remained the rest of his life. He first served as an economic advisor to the Secretary of Agriculture, Henry Wallace. He also served on the National Recovery Association's (NRA's) Consumer Advisory Board. In 1935, he moved over to the Industrial Section of the Natural Resources Committee; finally, in the early 1940s, he worked at the Bureau of the Budget. ${ }^{119} \mathrm{He}$

118. SCHWARZ, supra note 12, at 81-82 ("It surprised many people when Berle became assistant secretary of nothing in 1933.").

119. RosenOF, supra note 61, at 31. Means died in the same house in Vienna, Virginia he and his wife, Caroline Ware, had purchased in 1935. Glenn Fowler, Gardiner C. Means, 91, Is Dead; Pricing Theory Aided U.S. Policy, N.Y. TiMES (Feb. 18, 1988) [hereinafter Means Obituary], https://www.nytimes.com/1988/02/18/obituaries/gardiner-c-means-91-is-dead-pricing-theory-aidedus-policy.html [https://perma.cc/DH5A-KEED]. They called the 70-acre property "The Farm." SCOTT, supra note 64, at 8. Means and Ware donated most of The Farm to the Northern Virginia Regional Park Authority in 1980, retaining their house, which Ware donated after Means's death in 1988. John Bohn, Estate Built of History Becomes Public Garden, WASH. POST (Dec. 15, 1988), https://www.washingtonpost.com/archive/local/1988/12/15/estate-built-of-history-becomes-publicgarden/6bf7fe0a-0f37-4f87-8310-36dd4751a385/?noredirect=on\&utm_term=.290fcd42aba4 [https:// perma.cc/Q8FG-KM3V]. Today the property is known as Meadowlark Gardens. See Medowlark 
left the government in 1943 and landed in the think tank sector, first as an associate with the Committee for Economic Development from 1943 to 1958 and then with the Fund for the Republic from 1957 to 1959 . He remained an entrepreneur: in 1951 he started a business raising and selling zoysia grass, an enterprise he continued until 1963, when he was 67 years old. He thereafter continued to consult and write until his death in 1988, at 91 years of age. ${ }^{120}$

The one thing Means never did was take up an academic appointment. An outsider in his own profession, he never sought one. ${ }^{121}$ Although he thought of himself as a macroeconomist, he tends to be remembered as an institutionalist. ${ }^{122}$ There are good reasons for the institutional appellation. Like Thorsten Veblen and the other institutionalists, he engaged in historical evolutionary analysis of the economy, and his explanations elevated institutional structure over external factors. ${ }^{123}$ As such, his period of greatest influence was during FDR's first term, when the NIRA was put into place and planning correctives to free markets had their greatest prestige.

It bears noting that Means and the other leading institutionalists in the administration, Rexford Tugwell and Mordecai Ezekiel, disapproved of the NIRA's planning apparatus. The NIRA's executory arm, the NRA, featured sectoral planning by private actors under public auspices. ${ }^{124}$ For Means and his cohort, coordination needed to be effected on an overall basis in a process free of domination by business people - they, after all, were the very administrators whose pricing decisions needed to be overruled. ${ }^{125}$ In Means's more particular corporatist vision, a public agency should promulgate price and production policies generated as the balanced outcome of bargaining among representatives of business, labor, consumers, and government. ${ }^{126}$

The NIRA's collapse came at the expense of the institutionalists' reputations. Planning had failed, and no one was interested in the even more invasive iteration they advocated. ${ }^{127}$ Moreover, neo-Keynesian economists were on the scene promising a less heavy-handed mode of economic correction. Keynes diagnosed the problem underlying the Great

\footnotetext{
Parks, History, NOVA PARKS, https://www.novaparks.com/parks/meadowlark-botanical-gardens/ history [https://perma.cc/9M5M-2BSR].

120. SAMUELS \& MEDEMA, supra note 68, at 7-8; SCOTT, supra note 64, at 169.

121. Id. at 143 .

122. RoSENOF, supra note 61, at 30-31; see also SAMUELS \& MEDEMA, supra note 69, at 3-4 (describing Means as an institutionalist and as post-Keynesian).

123. ROSENOF, supra note 61 , at 5-6, 13-14.

124. Id. at 39 .

125. Id. at 15,38 .

126. Id. at $39-40$.

127. Id. at 17 .
} 
Depression as a climate of weak investment incentives incident to the modern economy and prescribed a cure in the form of government stimulus of investment. ${ }^{128}$ Means's period of influence ended abruptly in 1939, when, after a sharp debate, the neo-Keynesian economist Alvin H. Hansen, who had an investment-based theory of secular stagnation, displaced him at the National Resources Planning Board. ${ }^{129}$

Hansen's Keynesianism would be eclipsed in turn in the post-war economic expansion-secular stagnation no longer made sense once people were moving to Levittown and watching Leave It to Beaver on their new televisions. Keynesians still ruled, but in a new fusion with orthodox economic theory. The economy was now deemed to be fundamentally sound, as had been the case before 1929, but also was deemed to need short-run fine tuning pursuant to a mechanistic formula. ${ }^{130}$ Means, whose central ideas remained in place through his adult life, drifted further into the wilderness. ${ }^{131}$

Berle, in contrast, made a few crucial post-war adjustments and continued to occupy the national stage as a leading public intellectual. ${ }^{132}$ He told a happy story. New Deal reforms had solved the accountability problem identified in The Modern Corporation. ${ }^{133}$ The management incentive problem was under control, even though managers remained insulated from capital market pressures. ${ }^{134}$ A big stick state watched over them instead. ${ }^{135}$ To keep the state at bay, managers were forced to keep the public satisfied with jobs and growth. ${ }^{136}$ Thus constrained, managers amounted to quasi-civil servants. ${ }^{137} \mathrm{We}$ had, in effect, arrived at the higher

128. Id. at 22 .

129. Id. at $42,66-68$.

130. Id. at 2 .

131. SAmuels \& Medema, supra note 69, at 5 (noting also that Means made slight reformulations in response to criticism and changes in circumstances).

132. See generally Robert B. Thompson, Adolf Berle During the New Deal: The Brain Truster as an Intellectual Jobber, 42 SEATTLE U. L. REV. 663 (2019).

133. Adolph A. Berle, The American Economic Republic 82, 91 (1963) [hereinafter BERLE, REPUBLIC] (describing an "American economic republic" in which the state and the economy were interdependent, with the state taking ultimate responsibility for economic results and exercising the higher level of power).

134. Adolf A. Berle, JR., The 20th Century Capitalist Revolution 36-37 (1954) [hereinafter BERLE, 20TH CENTURY].

135. The state intervened only to stabilize the organizational lines and performance of private producers. BERLE, REPUBLIC, supra note 133, at 99.

136. Id. at 169; Adolph A. Berle, JR., Power Without Property: A New Development in AMERICAN POLITICAL ECONOMY 122 (1959) [hereinafter BERLE, POWER Without Property].

137. BERLE, REPUBLIC, supra note 133, at 88 . Berle's description had a theoretical counterpart in John KenNeth Galbraith, The New Industrial State (1967). Galbraith's picture leaves the competing groups free to make their own rules, subject to government intervention to assure that excessive power does not accrue to one group. Free competition is allowed to operate on a day-to-day 
evolutionary plateau called for in Book IV, Chapter IV and the close of Means's dissertation.

Interestingly, Berle's post-war descriptions of the economy amounted to notes on a lecture by Gardiner Means. Product markets, said Berle, were incomplete, and price did not match supply and demand. The industrial production machine, he asserted, could bring forth limitless goods ${ }^{138}$ but also presented persistent problems. Overcapacity gave management the discretion to set the level of production wherever it wanted; at the same time, labor tended toward oversupply. This led to an unpalatable either-or: either too many goods were produced or unemployment was too high. Market correction implied catastrophic fluctuations and intolerable costs: starvation for labor and bankruptcy for firms. ${ }^{139}$ The solution to the problem lay in a planned equation of supply to demand. ${ }^{140}$ Absent planning, asserted Berle, the economic conditions that had brought about the Depression would have recurred in the early 1960 s. ${ }^{141}$ A point of difference with Means opened up only at this point in the discussion. Means, as we have seen, had never been satisfied with the mode and character of federal price regulation. Berle was content with private planning in the industrial oligopolies ${ }^{142}$ accompanied by direct government intervention in the regulated industries. ${ }^{143}$

The economic and political conditions that supported Berle's sanguine political economy were fast disappearing at the time of his death

level, but in an administered economy that guards against excessive competition. The need for countervailing power precludes resort to market competition to choose the winners.

138. Adolf A. Berle, Power Without Property 176 (1967) [hereinafter Berle, Power]. Berle expressed no concerns about incentives to innovate within big firms - there was no way to tell whether development worked better inside or outside; the important thing was that the capital was there inside. Id. at 209-13.

139. BERLE, REPUBLIC, supra note 133 , at $78-79,82$. Berle observed that, absent regulation, conditions in 1962 resembled those of 1930, heralding another depression. Id. at 217.

140. BERLE, 20TH CENTURY, supra note 134, at 11-12.

141. BERLE, REPUBLIC, supra note 133, at 217.

142. His description of the oligopolies was pure Means: within a concentrated industry, competition amounted more to a struggle for power to balance supply and demand than to a struggle to gain market share through price competition. Competition continued within the industry in the limited sense that one firm could not set prices at will. Id. at 103-04. Meanwhile, abuse of economic power called for strong governmental responses. BERLE, POWER, supra note 136, at 129.

143. Industry-specific regulatory mechanisms controlling entry, exit, and prices remained in place over banking, ground, and air transport, public utilities, broadcasting, petroleum, and shipping. BERLE, 20TH CENTURY, supra note 134, at 49. 
in $1971 .{ }^{144}$ Their complete disappearance in the stagflation of the $1970 \mathrm{~s}^{145}$ had negative implications for his posthumous reputation. He lingers in the memory more for The Modern Corporation and his work on corporate law than for the post-war political economy that made up his main body of work. Stagflation, which combined recession with inflation, also brought down post-war Keynesianism, a theory which had no way to explain it.

Ironically, stagflation also meant vindication for Means, who did have a theory. Means had reemerged as a giver of Congressional testimony when inflation became a policy concern in the 1960s. ${ }^{146} \mathrm{He}$ was also the first economist to identify and describe a bout of stagflation, a task performed in a Preface to the 1967 edition of The Modern Corporation. ${ }^{147}$ The next generation - the post-Keynesian macroeconomists - would view him as a valued precursor. ${ }^{148}$

\section{PALO ALTO, 1982 AND BEYOND}

Means took his ideas on stagflation to the Hoover Institution conference in 1982, combining them with reflections on The Modern Corporation and the Great Depression in a symposium piece that amounted to a reprise of the high points of a long, distinguished career.

It was as if his $\mathrm{Ph}$.D. dissertation was getting a new section to account for recent developments in practice. Means offered a two-part analysis. In the first part, Means explained why a rational manager might find it convenient to raise prices even as demand was falling-a practice he called "perverse pricing." 149 He sketched out various scenarios. In one case, a manager working with fixed costs, variable costs, and a total profit target sees demand and output fall. Raising the price makes sense so long as it facilitates attainment of the profit target. ${ }^{150}$ Alternatively, the manager is comfortable with a fall in demand because overcapacity deters new entrants even as a price increase protects return on capital. ${ }^{151}$ In a third

144. Berle, a New Dealer until the end, had parted company with the New Left, which didn't buy his happy story. See Albin Krebs, Adolf A. Berle Jr. Dies At Age of 76, N.Y. Times (Feb. 19, 1971), https:/www.nytimes.com/1971/02/19/archives/adolf-a-berle-jr-dies-at-age-of-76-lawyereconomist-liberal-leader.html.

145. For a description of the staglflation of the 1970s, see Robert B. Barsky \& Lutz Kilian, $A$ Monetary Explanation of the Great Stagflation of the 1970s (Nat'1 Bureau of Econ. Research, Working Paper No. 7547, 2000), http://www.nber.org/papers/w7547 [https://perma.cc/4WD7-QFKS].

146. Means Obituary, supra note 119. His book GARDINER C. MEANS, PRICING POWER AND THE PUBlic InTEREST: A STUDy BASED ON STEEL (1962), had some influence.

147. Adolf A. Berle, Jr. \& Gardiner C. Means, The Modern Corporation and Private PROPERTY xlv-xlvi (Routledge 2d ed. 1991) (1932). Means identified it in the period 1953-1958.

148. ROSENOF, supra note 61, at 172.

149. Means, Corporate Power, supra note 86, at 476-77.

150. Id. at 477-78.

151. Id. at 478 . 
case, the price administrator at one firm puts through a raise and inflationary expectations cause the rest of the industry to follow. ${ }^{152}$ In all three cases the inflation occurs even as too little money is buying from well-stocked shelves rather than the classic inflationary case of too much money chasing too few goods. ${ }^{153}$ But the classic case could also occur in a stagflation context if corporate administrators raised employee pay absent a justificatory productivity increase. ${ }^{154}$

But why should perverse pricing in one sector trigger economy-wide inflation in an economy experiencing falling demand? We proceed to the second part of the analysis and return to the duopolistic economy described in the dissertation. So long, said Means, as the classically competitive part of the economy outweighed the sector with administrative competition, most prices went down in a recession and a Keynesian program of monetary and fiscal correctives could work. But there was a tipping point- "the great divide"-at which the administratively competitive sector was large enough to cause more prices to go up than down despite a fall in demand. Inflation and recession would combine accordingly. It was a dangerous place to be, generating self-fulfilling inflationary expectations. ${ }^{155}$

Means also had thoughts about what to do. He had a notion of a "natural" price. Perverse pricing occurred in a short-term frame as managers divided fixed costs and profit by current production volume. Long-term pricing would work better for the economy and get us closer to the natural price-fixed costs and profit would be divided by average projected output over a period of years. ${ }^{156}$ Means also was more moderate than he formerly had been in regard to implementation. He acknowledged that private planning had been known to succeed and projected that individual firms might well learn to correct their pricing practices and opt for a long-term approach. ${ }^{157}$

What was moderate for Means must have sounded recklessly interventionist to the neoclassical economists gathered at Hoover in 1982. ${ }^{158}$ The orthodox view of an inherently self-correcting economy,

152. Id. at 479 .

153. Id. at 476 .

154. Id. at $478-79$.

155. See id. at 480 .

156. Id. at 482 .

157. Id. at 482, 485 (citing the Committee for Economic Development, formed by business leaders in 1945, to work with the Commerce Department to avoid post-war recession).

158. It should be noted that the commentator on Means's paper, Carliss Baldwin of Harvard Business School, did not offer a flat, classical rejection of Means. Baldwin's comment was a measured discussion in which she pointed out where Means's views were compatible with the current pricing literature and where they were not. See Carliss Y. Baldwin, Administered Prices Fifty Years Later: A 
dispatched to the wilderness for the half-century after 1932, was returning to the mainstream in response to the policy failures of the 1970s. ${ }^{159}$ Many of those responsible for its articulation as a theory of the firm-Demsetz, Fama, and Jensen - gave papers at Hoover. ${ }^{160}$ And those who would soon be responsible for the new theory's cross-disciplinary arbitrage to law, Easterbrook and Fischel, were in the audience. ${ }^{161}$

One suspects that Means was well able to handle himself, even in that crowd and at 85 years of age. Still, it was a moment of radical change going against everything he stood for. Not only was orthodoxy back and full of energy in the academic world, but 1982 was the year in which inflation finally started to fall and the stock market finally advanced beyond its early 1970 s peak. ${ }^{162}$ The Reagan expansion was on and it finally solved the stagflation problem. ${ }^{163}$ Means's theory of perverse pricing, an in-the-moment intervention only a year earlier, had suddenly become history.

But there were twists and turns in store for the orthodox restoration as well, as least so far as concerned The Modern Corporation. The idea at the conference was to consign the separation of ownership and control to the dustbin of history on the occasion of its half century. The papers and comments were impressive and the participants doubtlessly left Palo Alto with a sense of a job well done.

Easterbrook and Fischel thereafter successfully took the new orthodoxy to corporate legal theory, turning what was implicit in Jensen and Meckling's original principal-agent model, ${ }^{164}$ along with the papers presented at Hoover, into a sequence of normative assertions. Their contractarianism offered an overarching account of successful marketbased control of corporate governance, an account that banished any

Comment on Gardiner C. Means: Corporate Power in the Marketplace, 26 J. L. \& ECON. 487, 48896 (1983).

159. William W. Bratton, The Separation of Corporate Law and Social Welfare, 74 WASH. \& LEE L. REV. 767, 777-80 (2017).

160. For a review of the literature, see William W. Bratton Jr., The Nexus of Contracts Corporation: A Critical Appraisal, 74 CORNELL L. REV. 407, 415-20 (1989).

161. See Williamson, supra note 26.

162. A look at the Macrotrends 100-year Dow Jones Historical Chart confirms this. The chart is CPI-adjusted and shows an historical low of 2,110 in June 1982. The market turns up in August and then moves up more sharply in September, finishing the year at 2,703. It continues its upward path but for blips in 1987 and 1989 until the collapse of the tech bubble in 2000. Dow Jones-100 Year Historical Chart, MACROTRENDS, https://www.macrotrends.net/1319/dow-jones-100-year-historicalchart [https://perma.cc/BT3G-B2AY].

163. There were two stagflation episodes: 1973 to 1975 and 1979 to 1982 . See Barsky \& Killian, supra note 145 , at 2 .

164. See generally Michael C. Jensen \& William H. Meckling, Theory of the Firm: Managerial Behavior, Agency Costs and Ownership Structure, 3 J. FIn. ECON. 305 (1976). 
problems stemming from separated ownership and control. ${ }^{165}$ There followed a claim that the inherited governance regime was economically rational, ${ }^{166}$ and there should be a presumption against having any more corporate law than already exists. ${ }^{167}$ The account's plausibility much depended on a vigorous takeover corrective.

But hostile takeovers ceased in the wake of the economic collapse of 1989 and failed to restart in tandem with economic recovery a couple of years later. $^{168}$ A public choice story circulated to explain their disappearance. Managers seeking renewed insulation from the markets had gone to state legislatures and appealed to state judiciaries to promote anti-takeover statutes and otherwise validate takeover defensive measures. ${ }^{169}$ The defenses appeared to be effective. It followed that in the post-takeover era agency costs were chronically and suboptimally high, undercutting Easterbrook and Fischel's market success story. ${ }^{170}$ Thus did the separation of ownership and control return to center stage as the problem that corporate law needed to solve, a late twentieth-century reenactment of Berle and Means's Depression era reversal of orthodoxy. But the replay came with its own twist. Although a law reform agenda was implied, it was not a law reform agenda following from a diagnosis of irretrievable market failure. To the contrary, the idea was to clear barriers so that market control could finally be made to work. Agency cost reduction through shareholder empowerment was the goal, and process reforms were thought to be a necessary means to the end. ${ }^{171}$

However, that diagnosis was itself upturned after the turn of this century, when hedge fund activists managed to overcome management insulation within the existing process context without the benefit of a law

165. See Bratton, supra note 160, at 408.

166. Frank H. EASterbrook \& Daniel R. Fischel, The ECONOMic Structure of CORPORATE LAW 315 (1991).

167. Id. at 21 .

168. For a brief history, see Bengt Holmstrom \& Steven N. Kaplan, Corporate Governance and Merger Activity in the United States: Making Sense of the 1980s and 1990s, 15 J. ECON. PERSP. 121, 123-33 (2001).

169. Roberta Romano, The Future of Hostile Takeovers: Legislation and Public Opinion, 57 U. CIN. L. REV. 457, 461-62 (1988).

170. See, e.g., Mark J. Roe, Chaos and Evolution in Law and Economics, 109 HARV. L. REV. 641, 644-45 (1996); see also Lucian Arye Bebchuk \& Mark J. Roe, A Theory of Path Dependence in Corporate Ownership and Governance, 52 STAN. L. REV. 127 (1999).

171. See, e.g., Lucian Arye Bebchuk, The Case for Increasing Shareholder Power, 118 HARV. L. REV. 833, 865-70 (2005) (recommending expansion of the zone shareholder legislative access to the corporate charter and the state of incorporation decision); Lucian A. Bebchuk, The Myth of the Shareholder Franchise, 93 VA. L. REV. 675, 699-702 (2007) (recommending a right to replace all incumbents every two or three years). 
reform assist. ${ }^{172}$ This was shareholder empowerment for real, and it came forth as a classic example of market correction. The correction was, of course, a long time in coming, but it was otherwise very much along the lines earlier predicted by Easterbrook and Fischel. It also implied yet another eclipse for Berle and Means. Gilson and Gordon accurately captured the moment when, in 2013, they observed that the separation of ownership and control has disappeared because shareholders now value (and exercise) their franchise to shape business policy. ${ }^{173}$

\section{CONCLUSION}

This essay recounts a succession of successes and comeuppances and comings and goings. First comes an external shock in the form of a Great Depression. Reacting to it, Berle and Means depose the reigning classicists, who querulously reject the theoretical part of Means's dissertation on their way out. Berle and Means's new corporatism then enjoys a brief ascendance but quickly implodes, compromising Means's reputation and causing Berle to make major adjustments to stay relevant. Meanwhile, different sorts of Keynesians come and go in the background in response to the economy's performance; ironically, their short runs of influence were built into the very theory they deployed. An external shock again disrupts things with the stagflation of the 1970s. This consigns Berle to history even as it briefly returns Means to center stage. But its primary beneficiaries turn out to be the new purveyors of classical orthodoxy, who promptly move to remove The Modern Corporation from the policy stage once and for all. That goal proves surprisingly difficult to accomplish and only comes about decades later as an incidental effect of a twenty-first century hedge fund investment strategy.

The central actor in all of this is the economy, the performance of which consistently upends theories that ask too much in the way of coordination by its free market side or, alternatively, go too far in dismissing the free market's corrective capacity.

172. Ronald J. Gilson \& Jeffrey N. Gordon, The Agency Costs of Agency Capitalism: Activist Investors and the Revaluation of Governance Rights, 113 COLUM. L. REV. 863, 865, 867, 874 (2013). Governance rights, formerly devalued now, are employed for the purpose of value enhancement as the hedge funds use them in tandem with firm-specific informational investment and monitoring. Id. at 891. The hedge funds' appearance "should be seen as an endogenous response to the monitoring shortfall that follows from ownership reconcentration in intermediary institutions." Id. at 867 .

173. Id. at 865 . 